\title{
О протестантских влияниях действительных и мнимых: православные катехизисы от Стефана Зизания до Феофана Прокоповича
}

\author{
Маргарита А. Корзо \\ Институт философии РАН Москва \\ korzor@zmail.ru
}

\begin{abstract}
:
Feofan Prokopovich's contemporaries believed that his catechetical works contained elements of Protestant dogma. And in historiography it is commonly considered that Feofan's theological treatises became the channel for the penetration of Protestant dogma into Russian religious thought. Similar accusations were addressed to some Orthodox authors of the Polish-Lithuanian Commonwealth in the first half of the $17^{\text {th }}$ Century (Stefan Zizani and others), whose catechetical works received wide distribution in Russia and determined the vector of development of the Russian catechetical tradition. This article analyses what specific arguments were put forward by critics and from which theological position, and whether these accusations testify to the actual presence of elements of Protestant dogma in the Orthodox literature of the era, or whether we are dealing with a polemical argument.
\end{abstract}

Keywords:

Feofan Prokopovich, Stefan Zizani, catechism, Protestant influences in Orthodox letters, religious polemics

За Феофаном Прокоповичем в историографии устойчиво закрепилась репутация протестантствующего богослова. Репутация эта основана в первую очередь на отзывах его современников и в гораздо меньшей степени - на критическом анализе его богословских сочинений. ${ }^{.}$Обвиняя Феофана в симпатиях к чуждым православию идеям, его оппоненты ссылались в первую очередь на материал киевских лекций богослова, который был опубликован лишь во второй половине XVIII в. в несколько расширенном и отредактированном виде ${ }^{2}$, на его

\footnotetext{
В настоящем исследовании за пределами рассмотрения остается участие Прокоповича в составлении “Духовного Регламента" и церковных реформах петровского времени. В задачи автора также не входит анализ богословской системы Феофана во всей ее полноте; не будет предпринята и попытка ответить на поставленный еще в начале XX в., но до сих пор не исследованный в должной полноте вопрос, насколько глубоко Феофан усвоил приписываемые ему протестантские идеи и в какой степени данные идеи via его труды оказались восприняты позднейшим православным богословием (А. Bukowski, "Zur Frage der Abhängigkeit der russisch-orthodoxen Theologie vom Protestantismus," Zeitschrift für Katholische Theologie 37 (1913): 675-681). Отдельные подходы к решению данной проблемы сформулированы С.О. Шкіль (Вплив ідей Протестантизму на формування світогляду Феофана Прокоповича. Диссертация на соискание уч.степени канд. философ. наук (Киев, 2004)), который также настаивал на том, что не корректно выносить вердикт о "неправославии" Феофана с позиций только лишь современного православного богословия, без учета оценки его вероучительной системы современниками.

${ }^{2}$ Не сохранилось развернутых критических высказываний современников о богословской сумме Прокоповича, хотя известно, что еще в киевский период жизни Феофана состоялось несколько диспутов вокруг этих лекций как в Академии, так и в Братском монастыре, на которых Прокопович был обвинен в арианстве (В.М. Ничик, Феофан Прокопович (Москва: Мысль, 1977), 166).
} 
брошюру о евангельских блаженствах и толкование Декалога. ${ }^{3}$ В данном исследовании мы остановимся лишь на последнем сюжете.

Понимание Прокоповичем Декалога реконструируется главным образом из трех его сочинений: Книжицы, въ ней же повесть о распре Павла и Варнавы съ іоудейсттвующими, и трудность слова Петра Апостола о неудобьносимомъ законномъ иге пространно предлагается, ${ }^{4}$ Первого учения отроком и Сокращенного христианского учения. Судьбы данных сочинений были очень разными. Книжица составлялась еще в киевский период жизни Феофана в 1712 г. и долго имела лишь ограниченное распространение, поскольку впервые была опубликована в конце столетия: в 1782 г. в Лейпциге вышел латинский перевод Книжицы, а в 1784 г. в Москве - отдельной брошюрой русская версия. Первое учение отроком (1720) переиздавалось многократно и на протяжении всего XVIII столетия служило основным школьным катехизисом в Российской Империи: указом Святейшего Синода от 1723 г. учебник был введен во всеобщее употребление при обучении не только духовных лиц, но и мирян. ${ }^{5}$ Сокращенное христианское учение, составленное Феофаном в 1731-1733 гг. и известное в рукописной форме как Краткая сказания ${ }^{6}$, было опубликовано в 1765 г., то есть уже после смерти Прокоповича. На это сочинение не сохранилось никаких критических отзывов и нет положительных свидетельств о том, что данный катехизис использовался в школьной практике в России. С другой стороны, сочинение было полностью воспроизведено в 1790 г. в Букваре языка славенскаго Львовского Ставропигийного Института и распространялось на украинских землях, вошедших к тому времени в состав империи Габсбургов.

В Книжице Феофан выстраивает свое рассуждение вокруг слов апостола Петра в Деян 15:10 и из трех разновидностей полученных Моисеем от Бога законов нравоучительного, обрядового и судебного - ограничивается рассмотрением лишь закона нравоучительного, сводя его исключительно к предписаниям Декалога. Сочинение затрагивает целый ряд богословских сюжетов, но основной его пафос состоит в том, что поврежденному грехом человеку не под силу всецело следовать и исполнять заповеди; и коль скоро это невозможно, то и простым “законотворением” нельзя ни оправдаться, ни спастись.

Книжица вызвала сильное недовольство у некоторых современников Прокоповича. Против нее были составлены как минимум два полемических сочинения: местоблюстителя патриаршего престола Стефана Яворского, ${ }^{7}$ которое А.Б. Григорьев датирует между 1712-1713 гг., ${ }^{8}$ и ректора Киевской Академии Феофилакта (Лопатинского). Трактат последнего Иго Господне благо и бремя его

\footnotetext{
3 П.А. Червяковский, “Введение в богословие Феофана Прокоповича,” Христианское чтение 7-8 (1877): 32-33; L. Müller, Die Kritik des Protestantismus in der russischen Theologie vom 16. bis zum 18. Jahrhundert (Mainz: Verlag der Akademie der Wissenschaften under der literatur, 1951), 52-90.

${ }^{4}$ Далее: Книжица.

5 Полное собрание законов Российской Империи. Собрание I, Т. VII (Санкт-Петербург, 1830 ): № 4172.

${ }^{6}$ ОР РНБ. Ф. 487. Собрание Н.М. Михайловского. F. 95. Л. 263-30о об. См.: В.В. Майков, “Заметки о Катихизисе Феофана Прокоповича," Сборник статей в честь Дмитрия Фомича Кобеко от сослуживцев по Императорской Публичной Библиотеке (Санкт-Петербург, 1913), 215.

7 ОР ГИМ. Собрание Уварова. № 275-1ㅇ․ Рукопись без датировки. Публикация подготовлена А.Б. Григорьевым (Вестник ПСТГУ. Серия I: Богословие. Философия 1 (39) (2012): 87-113; 2 (40) (2012): 113138).

${ }^{8}$ См.: А.Б. Григорьев, “Сочинение митрополита Рязанского и Муромского Стефана Яворского 'Иго Господне благо и бремя Его легко,” Вестник ПСТГУ. Серия І: Богословие. Философия 6 (38) (2011), 105.
} 
легко, си есть, законъ Божій, с заповедьми свочми от призрачных, новоизмышленных тяжестей и неудобств противнических свобожден ${ }^{9}$ генетически связан с сочинением Яворского, но создавался позднее, значительно больше по объему и кругу рассмотренных сюжетов. ${ }^{10}$ Яворский впоследствии отчасти повторил “заблуждения" Феофана в одном из писем 1718 г. в связи с поручением Петра I поставить Прокоповича и ряд других иерархов на “вдовствующие престолы”."

Оба критика нигде не называют Прокоповича по имени, но именуют его “противником" или рассуждают абстрактно о “нынешних противниках" истинного православного учения. Изложенные в Книжице воззрения оппоненты Прокоповича проинтерпретировали таким образом, что Феофан, якобы, полностью “отменяет" Закон нравоучительный; или, другими словами, он считает, что заповеди Ветхого Завета в полной мере на христиан не распространяются и что принципиальная неисполнимость Закона в силу поврежденности человеческой природы совершенно обесценивает значение добрых дел для спасения, которое возможно для человека Нового Завета только верой.

Обращает на себя внимание, что критики Прокоповича в этих двух пунктах выстраивают свою аргументацию, воспроизводя - вольно или невольно аргументацию посттридентского католического богословия, которое считало, что введенное протестантами противопоставление Закона (=Декалога) и Евангелия (=заповедей Христа) совершенно лишало десятословие обязывающей силы и делало бесполезными для спасения любые добрые дела. Подобное категоричное понимание протестантской позиции было зафиксировано уже в одном из постановлений Тридентского собора: “Если кто утверждает, что нет другой заповеди в Евангелии, кроме веры, что остальные не имеют значения, что они не предписаны и не запрещены, но безразличны, или что десять заповедей не имеют никакого отношения к христианам, да будет анафема."

Весьма примечательно, что критиками Книжицы выступили не великороссы, но те представители православного духовенства, которые, как и Прокопович, прошли через киевскую систему образования, испытавшую сильное влияние католической схоластики. И в этой связи закономерно возникает вопрос: в какой степени оппоненты Прокоповича анализировали в данном конкретном случае его собственные воззрения, опираясь на свое знание протестантского вероучения, а в какой степени они просто воспроизводили существующие католические штампы о протестантских традициях, то есть смотрели как на протестантизм вообе, так и на “протестантизм” Феофана - используя меткое выражение Д.Г. Извекова “раздраженными глазами католиков”?'3 Подобными “глазами католиков” для них могли быть не столько постановления Тридентского собора, сколько фундаментальный труд итальянского иезуита Роберто Беллармино (1542-1621): из

9 ОР БРАН. Шифр 31.4.28. См. также: Д.Г. И[звеков], “Один из малоизвестных литературных противников Феофана Прокоповича,” Заря. Журнал учено-литературный и политический, издаваемый В. Кашпиревым 8 (1870): 1-35.

${ }^{10}$ А.Б. Григорьев, “Сочинение митрополита Рязанского и Муромского Стефана Яворского,” 103.

" “Посланіе Стефана Яворского, Митрополита Рязанского и Мурамского, къ Преосвященнымъ Алексію Сарскому и Подонскому и Варлааму Тверскому и Кашинскому, объ ученіи Іеромонаха Феофана Прокоповича," ЧОИДР 4 (1864), Смесь: 5-8.

12 "De iustificatione," Canones et Decreta Sacrosancti oecumenici Concilii Tridentini sub Paulo III. Iulio III. et Pio IV. pontificibus maximis (Rome, 1904), 32.

13 См.: “Из истории богословской полемической литературы XVIII столетия," Православное Обозрение II (2-е полугодие) (1871), 143. 
его многотомных Disputationes de Controversiis Christianae Fidei черпали свои знания о протестантизме и антипротестантские аргументы на протяжении всего XVII в. не только католические полемисты, но также Стефан Яворский в своем богословском компендиуме Камень веры. ${ }^{14}$ Уже современники Яворского подметили зависимость его антипротестантской аргументации от Беллармино и иных католических полемистов, утверждая также, что он учения протестантов или не знает вовсе, или извращает его. ${ }^{15} \mathrm{~K}$ аналогичному приему заимствования антипротестантских аргументов из католических сочинений прибегали и менее именитые современники местоблюстителя; ${ }^{16}$ не чурался подобных заимствований и сам Феофан Прокопович. ${ }^{17}$

Прокопович, конечно же, не утверждал, что Закон полностью отменяется Евангелием, а добрые дела - верой; он признавал, что Декалог сохраняет обязательную силу и для христиан, а Евангелие или вера во Христа просто дает человеку силы к исполнению этого Закона. Феофан пытался лишь акцентировать, что греховное состояние человеческой природы препятствует совершенному исполнению Закона, и что спасение нельзя сводить только лишь к внешнему совершению добрых дел. В обоих случаях за словами Прокоповича можно усмотреть как скрытую полемику с некоторыми течениями внутри католического богословия, которые могли ассоциироваться у внешнего наблюдателя с полупелагианством (против данных течений, хотя и с совершенно иных позиций, выступали и французские янсенисты), так и неприятие отдельных практик современной ему католической церкви, для которой внешние и формализованные формы “законотворения" или добрых дел “весили” на весах спасения гораздо больше, нежели искренняя вера в Бога. ${ }^{18}$

Здесь мы имеем дело с довольно парадоксальной ситуацией: оппоненты Прокоповича критикуют его “протестантизм," используя католическую аргументацию; Феофан же выступает с критикой отдельных католических идей и практик, опираясь на определенные протестантские воззрения. Так, в частности, говоря о конкретной роли Закона в жизни человека Нового Завета, Феофан выстраивает свое рассуждение в соответствии с протестантским учением о “трех функциях Закона.” Не разбирая специально функцию “политическую” (politicus), позволяющую ограничивать проявления социального зла в общественной жизни, Прокопович говорит о теологической или духовной роли Закона (usus theologicus seu spiritualis), когда последний предстает своеобразным зеркалом, показывающим человеку “величество и тяжестъ греха,” “дабы [человек] смотря на законъ,

\footnotetext{
${ }^{14}$ И.В. Морев, “Камень веры” митрополита Стефана Яворского, его место среди отечественных противопротестантских сочинений и характеристическия особенности его догматических воззрений (Санкт-Петербург, 1904), 212-216, 233-235, 242-243, др.; H. Koch, Die russische Orthodoxie im Petrinischen Zeitalter. Ein Beitrag zur Geschichte westlicher Einflüsse auf das ostslavische Denken (Breslau: Oppeln, 1929), 178.

15 “<...> Lutheranorum et Reformatorum <...> sententiam vel ignorare, vel pervertere..." См.: Acta Eruditorum, anno 1729 publicata Mai (1729), 229; $\quad$ URL: http://gallica.bnf.fr/ark:/12148/bpt6k500469/f233.item, просмотр 18.03.2017 г.

16 Н.В. Покровский, "Борьба с протестантскими идеями в петровское время и князь Михаил Кропоткин," Русский Вестник 101 (9) (1872), 225.

${ }^{17}$ П.А. Червяковский, "Введение в богословие Феофана Прокоповича," Христианское Чтение 1-2 (1878), 27.

18 O категорическом неприятии Феофаном католического схоластицизма см., например: R. Stupperich, Peter der Große und die Russische Kirche. Ausgewählte Aufsätze II (Möhnesee: Bibliopolis, 2004), 180 .
} 
познавалъ бы скудости своя.” Гя Главным аргументом для Феофана (как и для протестантских богословов) было Послание апостола Павла к Римлянам (в частности - “Но я не иначе узнал грех, как посредством закона” (Рим 7:7)). Это познание позволяет христианину осознать собственное бессилие и вину и, одновременно с этим, побуждает его уповать на волю Бога и стремиться к совершенному ее исполнению (“в законном ученіи аки в зерцале видящее неисправления наша, непрестанно да прибегаем к милосердію Божію верою во Христа." $)^{20}$ Именно эта последняя (или третья функция Закона), сформулированная впервые Филиппом Меланхтоном (1497-1560), ${ }^{21}$ но разделяемая также и некоторыми сторонниками кальвинизма, была важным шагом к признанию определенной ценности добрых дел для спасения человека в протестантском богословии лютеранского толка. Положение о третьей функции Закона вошло впоследствии в догматический свод лютеран Формулу согласия (1577). ${ }^{22}$

В пользу того, что Прокопович не отрицал важной роли Декалога в жизни христианина говорит и тот факт, что он включил толкование заповедей Ветхого Завета в свой школьный катехизис Первое учение, пытаясь выстроить именно на их основе кодекс практического поведения и основных христианских, а также по большому счету и гражданских обязанностей.

Необходимо отметить, что в издававшихся в России элементарных учебниках сам текст десятословия появляется лишь с 1630-х гг., но до выхода в свет учебника Прокоповича не встречалось какого-либо толкования заповедей Ветхого Завета в подобного рода литературе. Не стало исключением и небольшое катехетическое поучение Заповеди божия, и церковныя, и иная некая виновная спасению словеса (М., 1702), воспроизведенное потом в московских букварях 1704 и 1708 гг.

Объясняя в предисловии к читателю замысел своего учебника, Прокопович говорит, что именно Петр I пожелал, чтобы было составлено объяснение Декалога и напечатано в составе букваря, чтобы дети впредь осваивали азы грамотности не по псалмам и молитвам, но на тексте толкования Закона. ${ }^{23}$ Сама необходимость познакомить народ с десятословием проистекала из того, что верующие “в такой тме и грубости пребываютъ, что ниже когда слышали о законе Божии” и и даже самые богобоязненные из них “не ведая силы и закона Божия, многихъ своихъ греховъ не ведают." ${ }^{5}$ Речь шла о том, что формальное знание отдельных предписаний не означало, что верующие понимали, какие грехи могут скрываться за несоблюдением той или иной заповеди, а потому воспитатели должны были не только указывать детям на их провинности, но и объяснять своим подопечным, против какой конкретно заповеди данная провинность направлена. ${ }^{26}$

\footnotetext{
${ }^{19}$ Книжица, 107.

${ }^{20}$ Книжица, 142.

${ }^{21}$ Philip Melanchthon, "Examen eorum qui audiuntur ante ritum publicae ordinationis, qua commendatur eis ministerium Evangelii," Opera omnia . T. I (Wittenberg, 1562-1564): 309-309v.

22 Ю.Ф. Клуг, Происхождение “Формулы согласия.” История создания и краткое содержание “Формулы”. Пер. с англ. Е. Терехина (Минск: Фонд “Лютеранское наследие”, 20оо), 114-115.

${ }^{23}$ Первое учение отроком, 5-50б.

${ }^{24}$ Ibid., 3.

${ }^{25}$ Ibid., $20 б$.

${ }^{26}$ На необходимость в контексте каждой заповеди объяснять народу конкретные грехи указывал и Петр I в своих заметках относительно сочинения Феофана о евангельских блаженствах. См. “Заметки Петра I, предложенные Феофану Прокоповичу в качестве плана для книги О блаженствах против ханжей и лицемеров,” (И.А. Чистович, “Феофан Прокопович и его время,” Сборник статей,
} 
Подобная установка рассматривать Декалог в первую очередь как зеркало или отражение человеческих пороков получила свое выражение в том, что при толковании каждой конкретной заповеди говорится преимущественно о том, что заповедь запрещает, и перечисляется по пунктам, кто грешит против данного предписания; позитивные предписания в толкованиях десятословия занимают второстепенное место. В подобной установке можно усмотреть отзвуки лютеранского учения о первой функции Закона. С другой же стороны, практически все католические катехизисы XVII в. ограничивались при толковании Декалога практически исключительно перечнями греховных проступков, акцентируя тем самым негативный (запрещающий) смысл десятословия и отводя довольно мало места позитивному (предписывающему) смыслу. Подобный подход был отражением общей установки католической моральной теологии той эпохи, которая, будучи тесно связана с таинством покаяния, была озабочена в первую очередь сферой нравственно предосудительного (или греховного) нежели сферой нравственно совершенного (или добродетелью). А потому невозможно сказать со всей определенностью, какие конкретно конфессиональные образцы были в данном случае для Феофана приоритетными. Очевидно лишь то, что само вынесение заповедей Ветхого Завета на первое место в Первом учении было данью скорее лютеранской катехетической традиции: развернутое обоснование того, почему изложение христианского вероучения должно начинаться именно с Декалога, Лютер предложил еще в работе 1526 г. Немецкая месса. ${ }^{27}$ И уже с Краткого катехизиса 1529 г. подобная катехетическая модель становится доминирующей (хотя и не единственной!) в лютеранской традиции. ${ }^{28}$

Если попытаться резюмировать схематично изложенную выше дискуссию вокруг заповедей Декалога, то одним из ее объяснений может быть также взаимное непонимание двух сторон. Данное непонимание заметно уже на уровне ключевых для дискуссии понятий: если Феофан понимал под Законом исключительно ветхозаветные предписания, то для его критиков Закон с необходимостью включал и новозаветные установления, в первую очередь - Нагорную проповедь. Аналогичный критикам Феофана подход заметен и у молдавского господаря Димитрия Кантемира (1673-1732), проанализировавшего “заблуждения" Прокоповича в трактате Места примрачная в катихисисе, иже отъ без имяннаго автора на Славенском языке изданъ и “первое учение отроком" имянованъ естъ. ${ }^{29}$ Князь считает, что автор Первого учения совершенно несправедливо сводит “Закон Божий” исключительно только к десятословию, не включая в понятие “закон” предписания, данные Христом в Новом Завете: "На [поставленный в катехизисе] вопросъ, что есть законъ Божий <...> отвещати подобаше, яко Законъ Божий есть учение Еvаньелское еже по блаженному Павлу есть о Христе Іисусе.” В действительности существуют два Закона: Ветхого Завета и Нового Завета. Первый

читанных в Отделении русского языка и словесноости Императоской академии наукб Т. 4 (СанктПетербугр, 1868), 125-7.

27 W. Herbst, Evangelischer Gottesdienst. Quellen zu seiner Geschichte (Göttingen: Vandenhoeck \& Ruprecht, 1992), 69-87.

${ }_{28}^{28}$ T. Reroń, “Katechizmy w dobie Soboru Trydenckiegoб” Wrocławski Przegląd Teologiczny 7:1 (1999): 129143.

${ }^{29}$ ОР БРАН. Шифр 33.11.3 [Далее: Места примрачная]; описание рукописи: А.И. Бабий, В.М. Ничик, “Кантемир и Ф. Прокопович,” Идейные связи прогрессивных мыслителей братских народов (XVIIXVIII вв.) (Киев: Наукова думка, 1978), 118.

${ }^{30}$ Места примрачная, 13-13об. 
был дан иудеем “по жестокосердїю сердца ихъ," “Законъ же новаго завета полный благодати, свобождаетъ закона греха" ${ }^{11}$ и именно его изложение должно быть представлено в букваре.

$* *$

Обвинения в протестантских симпатиях отдельных православных богословов как следствие непонимания, а может и недостаточного знания нюансов протестантских вероучений встречались и в более раннюю эпоху. Речь идет об упреках, звучавших в адрес православных катехизисов Киевской митрополии конца XVI в. - первой половины XVII в.; катехизисов, которые оказали решающее влияние на становление московской катехетической традиции. ${ }^{32}$ При всем различии культурных и религиозных реалий, а также полемических контекстов, в которых звучали упреки в отходе от православного вероучения, между данной эпохой и временем Феофана Прокоповича можно усмотреть некоторое сходство в том, какую функцию выполняли антипротестантские выпады.

Наиболее частой претензией в адрес ранних православных катехизисов было обвинение в том, что они содержат “арианские" идеи. Одна из полемик развернулась вокруг несохранившегося катехизиса виленского православного богослова Стефана Зизания, датированного не позднее середины сентября 1595 г. $^{33}$ Содержательные упреки в адрес данного сочинения прозвучали на церковном соборе в Новогрудке 27 января 1596 г.: Стефану вменялось то, что он, якобы, отрицает, что Христос является заступником человека перед Богом (“иже дей господь нашъ Іисусъ Христосъ ходатаемъ нашимъ до отца бога не есть”) и подтверждает свое богословское мнение не надлежащими ссылками на отцов Церкви, но исключительно не имеющими доказательной силы абстрактным рассуждением (“только силогизмою.”) ${ }^{34}$

Любопытно, что похожие обвинения в адрес сочинения Стефана прозвучали и из уст некоего католика Шченсного Жебровского в брошюре Kqqkol ktory rozsiewa Stephanek Zizania w Cerkwiach Rvskich w Wilnie (Вильно, 1595), основной пафос которой была защита церковного единства и призыв к унии. Стефан же Зизаний, по мнению автора брошюры, препятствовал церковному единству, сея среди православных ложное учение. Жебровский пересказывает толкование Стефаном 7го артикула символа веры (“И восшедшего на небеса, и сидящего одесную Отца...”), в котором, якобы, отрицалась роль Христа как заступника человека перед Богом:

Мы осуждаем различных еретиков, которые, умаляя достоинство Сына Божьего и т.д., называют его ходатаем перед Отцом. Поэтому мы веруем, что сидящий одесную Бога Отца обладает и равной славой и достоинством с Богом Отцом, а

\footnotetext{
${ }^{31}$ Ibid., 780б.-79.

32 М.А. Корзо, Украинская и белорусская катехетическая традиция конца XVI - XVIII вв.: становление, эволюция и проблема заимствований (Москва: Канон+, 2007).

33 Есть все основания полагать, что сочинение было впоследствии перепечатано как Обясненіе изложенїя Никейского, и Константинопольского С ммволу, двунадесяти арътыкуловъ веры христіянское в составе сборника Собрание вкратце словес (Угорцы, 1618). См.: Корзо, Украинская и белорусская катехетическая традиция, 245-251.

34 Wladimrus Milkowicz, Monumenta confraternitatis Stauropigianae Leopoliensis (Leopolis, 1895), T. I: $693-5$.
} 
не ме́ньшей властью. И не есть ходатаем, ибо тот, кто перед кем-то ходатайствует, ни восседать с ним рядом не может, ни равного достоинства с ним быть. ${ }^{35}$

Данный тезис, как упоминалось выше, стал предметом обсуждения на январском соборе 1596 г., после которого Стефан и ряд братских священников внесли в гродские книги протест, обосновывая правоту своей позиции ссылкой на недавно изданный в Остроге Маргарит Иоанна Златоуста (11.VI.1595):

Иж сын божий единородный сходатаивши намъ спасеніе взышол превыше небес всех, и к тому не молит ся вжо за нами до отца, але седитъ на правицы его, ни проповедуетъ, ни молит ся толко о всех православных, съ отцемъ и духомъ светымъ покланяемый и славимый естъ, акто его причынцою до отца и своимъ молебникомъ и не ровной владзы съ отъцемъ быти, верыти учытъ, тотъ естьотъ светыхъ богоносных отецъ давно проклятъ. ${ }^{36}$

Складывается впечатление, что принявшие позднее унию отцы собора и Жебровский, с одной стороны, и Стефан, с другой, друг друга не понимали, потому что говорили о несколько разных вещах. Непонимание могло быть вызвано и некоторой категоричностью отдельных формулировок Стефана. Его полемический выпад был направлен, как представляется, против набиравших в Речи Посполитой силу антитринитариев - последователей Франческо Станкара, считавших Христа посредником только в силу его человеческой природы и отрицавших божественную природу Спасителя, видя в нем только человека, пусть и наделенного от Бога особыми (благодатными) дарами. Спор о посредничестве Станкар инициировал еще весной 1559 г., но эта тема оставалась актуальной в богословских диспутах польско-литовских кальвинистов и на рубеже XVI-XVII вв. Для Стефана было важно акцентировать равное достоинство первого и второго лиц Святой Троицы (и, тем самым, отстоять и сам догмат троичности), в то время как его оппоненты считали, будто братский проповедник вообще отрицает, что и после вознесения Христа на небо возможно достичь спасения благодаря его заступничеству (обращенным к нему молитвами, например); и, таким образом, встает на позиции антитринитаризма.

Неверная интерпретация посреднической миссии Христа и тяготение к “арианству” вменялись впоследствии братскому проповеднику и униатскими полемистами: “...старый баламут Стефанко Зизания... написал в своих книжках, иж Христос теперь, седечи на правицы бога отца своего, вже не ходатайствует о нас,”писал Киевский униатский митрополит Ипатий Потей в сочинении Гаръмония альбо согласие веры, сакраменътов и церемоний святое восточъное церъкви с костелом рымъским (Вильно, 1608)37 Также и перешедший в унию Мелетий Смотрицкий акцентирует данную тему в разборе “ересей” Стефана. ${ }^{38}$

Еще одним сюжетом, в контексте которого православные катехизисы зачастую упрекались в их тяге к антитринитаризму, был сюжет об исхождении Святого Духа. Так, Жебровский обвиняет Стефана Зизания, что он выбросил filioque из текста

\footnotetext{
${ }^{35}$ Kąkol ktory rozsiewa Stephanek Zizania, 6 (перевод мой - M.К.).

${ }^{36}$ Monumenta confraternitatis, 699.

37 Цит. по: А.И. Анушкин, На заре книгопечатания в Литве (Вильнюс, 1970), 71-2.

${ }^{38}$ Exethesis abo Expostulatia to iest rosprawa miedzy Apologia y Antidotem o Ostanek btędow Haereziy y kłamstw Zyzaniowych, Philaletowych, Orthologowych, y Klerykowych uczyniona (Lwów, 1629), 43.
} 
символа веры Афанасия и исказил формулу исхождения, добавив туда уточнение “от самого Отца" (курсив мой - М.К.). Католические авторы и в XVI, и в XVII вв., защищая filioque, ссылались зачастую именно на исповедание, приписываемое Афанасию Александрийскому. Православные богословы с такой аргументацией были не согласны, утверждая, что греческий текст символа (т.е. без filioque) гораздо более древний и единственно верный. Добавление “от самого” могло быть сделано Стефаном в полемических целях: оно выступало одним из аргументов против католического учения о filioque. Уточнение “от самого" регулярно встречается впоследствии во многих православных изданиях первой половины XVII в., вызывая острую критику со стороны как католических, так и униатских полемистов, поскольку данная формулировка имела для них явный привкус антитринитаризма, интерпретировалась как попытка придать особый статус первому лицу Святой Троицы. ${ }^{39}$ Создается впечатление, что полемическая (=антикатолическая) заостренность некоторых формулировок православных катехизисов воспринималась их критиками как свидетельство зараженности православного вероучения “арианством”.

В православных катехизисах Речи Посполитой, также, как и в проанализированных выше сочинениях Феофана Прокоповича, можно, конечно же, найти мысли, которые очень схожи с протестантскими воззрениями. Не случайно защитника своей интерпретации посреднической миссии Христа Стефан Зизаний обретет впоследствии не в лице одного из своих собратьев по вере, но ректора социнианской академии в Киселине Остафия (Евстафия) Киселя. ${ }^{40}$ В катехетической литературе Киевской митрополии встречаются, например, идеи о том, что ветхозаветные таинства были не просто прообразом новозаветных, но таинствами в собственном смысле этого слова. ${ }^{41}$ В евьенском катехизисе 1611 г. дается определение церкови, которое вполне было приемлемо и для кальвинистов: “видомым пречистое евангелское науки случаючих, и правдиве таинъ христовыхъ оуживаючихъ, зебранемъ быти вызнаваю." ${ }^{2}$ Здесь нет, правда, упоминания о том, что только избранные Богом образуют истинную Церковь Христову, но названы два признака, которые в реформатской традиции выступали в качестве основных “знаков" истинной церкви. ${ }^{43}$ Примечательно, что Мелетий Смотрицкий, который был вероятным автором катехизиса 1611 г., впоследствии сам признавался, что некоторые из его ранних текстов “во всем страдают лютеранизмом.” ${ }^{44}$ С другой стороны, “саморазоблачение” Смотрицкого нельзя во всем принимать за чистую монету: его пафос в поздних сочинениях состоял в том, чтобы обосновать свой

\footnotetext{
39 J. Dubowicz, Hierarchia albo o zwierzchności w Cerkwi Bożey (Lwów, 1644), 93; Отдельные аргументы данной полемики изложены также в: Lithos abo Kamień... 1644, Архив ЮЗР 1/9 (1893), 381, 388, др.

${ }^{40}$ E. Giselius [Gelaziusz Diplic], Antapologia, abo Apologiey, ktorq do Przezacnego narodu Ruskiego przewielebney Ociec Melecyusz Smotrzycki... napisat, zniesienie (Б.м., 1632), 227-228, 286.

41 “Катехизісъ, албо вызнаніе веры святое соборное, апостолъское, въсходнее церкви," ЧИОНЛ 4 (1890), Приложения: 49.

42 "Катехизисъ албо короткое зебранье веры и церемоній Святое Соборное Апостолское Всходнее Церкви, Молитвы повседневные от многихъ святыхъ отецъ събраные,” 14об.

${ }^{43}$ Сравни: “Церковь везде, где в чистоте проповедуется и выслушивается Слово Божье и где Таинства совершаются по установлению Христову” (Ж. Кальвин, Наставление в христианской вере, Кн. 4. Гл. I. (Москва: Издательство Российского гуманитарного университета, 1999), 9.

${ }^{44}$ Цит. по: Макарий (Булгаков), История Русской Церкви, Кн. VI (Москва: Издательство СпасоПреображенского Валаамского монастыря, 1996), 444. Здесь, конечно, “лютеранизм” необходимо понимать как синоним протестантизма.
} 
отход от православия именно “порчей” православного вероучения под влиянием привнесенных из протестантизма “еретических" новшеств.

Обвинения в тяготении к протестантским идеям православного вероучения (некоторые из которых действительно были справедливы), а также упреки в непроясненности позиции православных богословов звучали из уст и других католических и униатских полемистов. Задачу активно противостоять проникновению идей протестантизма (в первую очередь - кальвинизма, но также и элементов антитринитаризма) поставил перед собой Киевский митрополит Петр Могила. При этом он парадоксальным образом и критиковал, и пытался преодолеть данные влияния обращением к католической традиции. На явной антипротестантской акцентированности сочинений митрополита и на взаимообусловленности антипротестантизма и католических симпатий Могилы настаивает и польский исследователь Марек Мельник: “Антипротестантизм Могилы ... естественным образом приводил к сближению с католицизмом (посредством заимствования выработанных там образцов антипротестантской полемики)," но “не означал, однако, выхода за пределы православной ортодоксии. Это, скорее всего, была попытка компромисса, которая состояла в использовании латинских образцов при одновременном сильном акцентировании византийской традиции." 45

В позиции Могилы можно усмотреть некоторую отдаленную аналогию с эпохой Прокоповича: Киевский митрополит - как позднее Лопатинский и Яворский ставит перед собой задачу противостоять протестантским влияниям (как реальным, так и мнимым) и критикует протестантские заимствования у своих собратьев по вере зачастую с позиций не православной традиции, но современного им католического богословия.

$* *$

Рассмотренные выше сюжеты, конечно же, не исчерпывают всего многообразия протестантских заимствований (как действительных, так и кажущихся) в катехетической литературе той эпохи, а также всего многообразия обвинений в протестантских симпатиях, прозвучавших из уст ревнителей православия или его конфессиональных оппонентов.

При этом протестантизм критиковался и теми авторами, которые сами подвергались обвинениям в увлеченности протестантизмом. Так, сочинения самого Прокоповича были не свободны от антипротестантских выпадов и аргументов, которые отчасти были уже подмечены исследователями. ${ }^{46}$ Феофан, в частности, выступал против тех, что порицал почитание икон, называя их “современными иконоборцами” и сравнивая их со сторонниками древних ересей ${ }^{47}$; отрицал учение о

\footnotetext{
${ }^{45}$ M. Melnyk, Spór o zbawienie. Zagadnienia soteriologiczne w świetle prawosławnych projektów unijnych powstatych w Rzeczypospolitej (koniec XVI - połowa XVII wieku) (Olsztyn: Wydawn. Uniwersytetu Warmińsko-Mazurskiego, 2001), 202. Об антипротестантских выпадах в Православном исповедании веры Могилы см.: Корзо, Украинская и белорусская катехетическая традиция, 388-91.

46 Д.Г. Извеков, "Проповедническая противупротестантская литература на Руси в первой половине XVIII в.," Православное Обозрение I (1-е полугодие) (1871): 90-95; Müller, Die Kritik des Protestantismus, $84-5$.

47 Слово о почитанїи святых иконъ, Феофан Прокопович, Слова и речи, Ч. 1 (Санкт-Петербург, 1760), 75-95.
} 
тотальном божественном предопределении ${ }^{48}$; обличал преувеличение последствий первородного греха для природы человека: “безумныи суть калвинскїи богословы учащїи быти естество человеческое такъ испорченное первороднымъ грехомъ, что всячески телесныхъ похотей и иныхъ естественныхъ склонностей преодолети не можетъ ... несправедливо и ложно говорятъ тїи, которыи [заповеди Ветхого Завета] тяжкими нарицаютъ." ${ }^{49}$ Последний выпад особенно важен в контексте упомянутой выше дискуссии о выполнимости заповедей Декалога и высказанных в адрес Прокоповича обвинений.

Почему же стала возможна ситуация, когда приверженцы одной и той же конфессии - православия - не понимали друг друга и интерпретировали одни и те же положения вероучения столь противоречивым образом?

Ответом на этот вопрос может быть то обстоятельство, что в то время не существовало единого эталона в православной традиции (или православных традициях), с помощью которого частное богословское мнение могло быть квалифицировано как каноническое или неканоническое. В то время как западные конфессии на протяжении второй половины XVI - первой половины XVII вв. кодифицировали свое вероучение в виде законченных догматических корпусов (католики - на Тридентском соборе (1545-1563); лютеране - в Книге Согласия 1580 г.; кальвинисты - на Дортрехтском синоде 1618 г.), православные церкви (греческая, киевская, московская) не располагали даже символическими книгами или соборно утвержденными сводами своего вероучения (конфессиями), которые могли служить в качестве догматического эталона. И данные своды формируются лишь постепенно, на протяжении всего XVII - начала XVIII вв. В Греческой церкви на статус конфессии претендовало выдающее явные протестантские симпатии Восточное исповедание христианской веры (1629) Патриарха Константинопольского Кирилла Лукариса; впоследствии - утвержденное на поместном Соборе 1672 г. Исповедание Иерусалимского патриарха Досифея, в совокупности с другими документами известное как Послание патриархов восточно-кафолической Церкви о православной вере. Для православных Киевской митрополии подобную функцию призваны были выполнять катехизисы митрополита Петра Могилы (в краткой форме: Киев, 1645; Москва, 1649; и в форме Православного исповедания веры (Москва, 1696)). В России на статус такого рода догматического компендиума претендовал опубликованный лишь в 1728 г. Камень веры Стефана Яворского.

Представленный выше пусть и фрагментарно материал позволяет также задаться вопросом, действительно ли речь всегда шла об обличении каких-то протестантских заимствований или за этой по видимости религиозной полемикой скрывалось (или потенциально могло скрываться) что-то иное?

Феофан, конечно же, заслужил часть высказанных в его адрес упреков: в его богословском наследии встречаются как явные, так и неотрефлексированные (не только им самим, но и его критиками!) протестантские заимствования. ${ }^{50}$ Другое

\footnotetext{
${ }^{48}$ Слово в день святых Апостолъ Петра и Павла, Феофан Прокопович, Слова и речи, Ч. 2 (СанктПетербург, 1761), 229-56.

${ }^{49}$ Слово о любви к Богу, Феофан Прокопович, Слова и речи, Ч. 3 (Санкт-Петербург, 1765), 269-70.

50 Они не ускользнули от внимания и лютеранских исследователей наследия Феофана: так, предпринятый М. Шианом критический разбор немецкой версии Первого учения отроком привел к констатации, что сочинение в значительной своей части выдержано в духе лютеранского 
дело, что заимствования эти заметны в меньшей степени на уровне фактического материала и в большей - в подходах и методах изложения богословского содержания. Протестантские симпатии Прокоповича носили скорее прагматический характер, ${ }^{51}$ были в первую очередь своеобразной реакцией на засилье католической схоластики той эпохи. Протестантизм для Феофана выступал также синонимом нового, просвещенного взгляда на вещи. ${ }^{52}$

Создается впечатление, что критика “протестантизма” Феофана была зачастую не столько спором по существу и разбором его личной богословской позиции ${ }^{53}$, сколько своеобразным полемическим приемом, проявлением консервативного взгляда на вещи или стремлением сохранить существующий status quo, способом заклеймить что-то новое. В пользу данного предположения говорит, в частности, то, что критики зачастую не только не различали протестантские конфессии (которые далеко не всегда были едины в трактовке тех или иных положений христианского вероучения!), но даже и не ставили перед собой такой задачи по различению. Так, Феофилакт Лопатинский и Маркелл Радышевский предпочитают употреблять полемически-безликое обвинение “ересь лютеранская и кальвинская." У Стефана Яворского можно встретить разведение точек зрения лютеран и кальвинистов; $;^{54}$ хотя и он не всегда последователен в этом различении.

В пределах Киевской митрополии звучавшее из уст как католиков, так и униатов обвинение православных в протестантизме (“арианстве”) выступало после Брестской церковной унии 1596 г. в качестве одного из весомых аргументов их неправоверия: те православные, которые пренебрегли единством с Римом, попали под влияние религиозных вымыслов протестантов, которые также от этого единства с Римом отпали. Так, например, саму акцию осуждения катехизиса Стефана Зизания невозможно понять вне контекста противостояния братского движения (к которому принадлежал и Стефан) и официальных церковных властей накануне заключения Брестской унии: осуждавший воззрения Стефана митрополит Михаил Рогоза принадлежал к той части православной иерархии, которая перешла впоследствии под юрисдикцию Римского Престола. Обвинения в зараженности идеями крайних сторонников протестантизма не утихают на протяжении всего XVII столетия: даже и в 1683 г. Иоанникий Галятовский сетует в Fundamenta na których łacinnicy jedność Rusi z Rzymem fundują на то, что униатский митрополит Киприан Жоховский открыто называет его и Лазаря Барановича арианами. В данном случае

вероучения (M. Schian, "Ein russisch-orthodoxer Kinderkatechismus aus der Zeit Peters des Großen," Theologische Studien und Kritiken 86 (1913): 140-152).

${ }^{51}$ В. Живов, Из церковной истории времен Петра Великого: исследования и материалы (Мовква: Новое литературное обозрение, 2004), 58.

$5^{2}$ Идея, высказанная еще Р. Штупперихом, была повторена Ю.В. Кагарлицким (“Текст Св. Писания в проповедях Феофана Прокоповича," Известия АН. Серия литературы и языка 56 (5) (1997), 40).

53 Хотя и это имело место: так, рассуждения оппонентов Прокоповича можно интерпретировать и таким образом, что они использовали сочинения Феофана как повод критически поговорить о протестантизме. Разбирая Книжицу, Стефан Яворский выступает “не столько против самого Феофана, который зачастую не высказывал приписываемых ему взглядов, сколько указывает на крайние протестантские воззрения, а также на те возможные последствия, к которым может привести <...> выбранная точка зрения" (цит. по: Вестник ПСТГУ. Серия I: Богословие. Философия 6 (38) (2011), 105). Не до конца остается проясненным и вопрос, в какой степени Яворский вообще был знаком с сочинениями Феофана? Не опирался ли он в своих выводах на изложение идей Прокоповича Гедеоном Вишневским? См. об этом: R. Stupperich, "Feofan Prokopovičs theologische Bestrebungen," Kyrios 1 (1936), 357 (перепечатано в: Stupperich, Peter der Große und die Russische Kirche, 183).

${ }^{54}$ Вестник ПСТГУ. Серия I: Богословие. Философия 2(40) (2012), 125, 130. 
речь шла скорее о полемическом приеме, когда антитринитарий (в случае книжников Киевской митрополии), а впоследствии обезличенный протестант (в случае Феофана) выступал в первую очередь как абстрактное обвинение, своего рода полемическое ругательство, низводящее оппонента до статуса еретика. И в этом контексте совершенно не имело значения, в каком объеме протестантские идеи действительно проникли в киевское, а затем и московское богословие. 